\author{
Г.О. СЛАБКИЙ', С.В. ДУДНИК²
}

\title{
ТЕНДЕНЦІї СТАНУ ЗДОРОВ'Я ДИТЯЧОГО НАСЕЛЕННЯ ТА ДОСТУПНОСТІ МЕДИЧНОЇ ДОПОМОГИ (за даними вибіркового опитування домогосподарств із дітьми)
}

\author{
${ }^{1}$ ДВНЗ «Ужгородський національний університет», м. Ужгород, Україна \\ 2ДУ «Український інститут стратегічних досліджень Міністерства охорони здоров'я України», \\ м. Київ, Україна
}

\begin{abstract}
Мета: вивчити, проаналізувати та визначити тенденції стану здоров'я дітей та доступності медичної допомоги домогосподарствам із дітьми за результатами вибіркових досліджень протягом 2012-2016 рр.

Матеріали і методи. Дослідження проведено на основі даних вибіркових опитувань домогосподарств із дітьми Державної служби статистики України щодо суб'єктивної оцінки стану здоров'я дітей та доступності медичної допомоги домогосподарствам із дітьми за період 2012-2016 рр. Використано методи: аналітичний, статистичний, порівняльний аналіз, системний підхід.

Результати. У ході дослідження, за даними суб'єктивної оцінки, визначено тенденції щодо оцінки стану здоров'я дітей, захворюваності та наявності хронічної патології у дітей, доступності медичної допомоги та її видів домогосподарствам із дітьми за період 2012-2016 рр.

Висновки. Встановлені тенденції стану здоров'я дитячого населення та незадовільний рівень доступності медичної допомоги вимагають оптимізації системи надання медичних послуг та медико-санітарної допомоги дитячому населенню країни в цілому.
\end{abstract}

КЛЮчОВІ СЛОВА: здоров'я дітей; доступність медичної допомоги; тенденції дитячого здоров'я; домогосподарства з дітьми.

Стан здоров'я і захворюваності дорослого населення будь-якої країни визначається станом здоров'я і досвідом на попередніх етапах життя людини, що потребує докладання зусиль на збереження здоров'я, починаючи 3 самого раннього дитинства, на розірвання негативних циклів дитячого і підліткового віку, що має сприяти тому, що діти і молоді люди зможуть стати здоровими, щасливими і компетентними особами, здатними зробити позитивний внесок у збереження власного здоров'я і розвиток суспільства. Навіть в матеріально благополучних суспільствах для досягнення поліпшення в галузі здоров'я дітей потрібно зрушення в бік загальнодержавного підходу і всеосяжних стратегій, що часто включає і системні зміни, з метою забезпечення справедливості стосовно показників здоров'я і благополуччя дітей і підлітків. На сучасному етапі у всьому Європейському регіоні ВООЗ вживаються заходи, спрямовані на захист й поліпшення здоров'я і розвиток дітей та підлітків, але в галузі зміцнення здоров'я та благополуччя і досягнення більшої соціальної справедливості має бути зроблено набагато більше. Інвестиції в розвиток дітей і підлітків, у тому числі протягом найкритичніших перших трьох років життя, не тільки приведуть до поліпшення показників здоров'я, але також принесуть користь в економічній і

(с Г.О. Слабкий, С.В. Дудник, 2018 соціальній сорерах. Для покращення здоров'я дітей у країнах Європейського регіонального бюро ВООЗ прийнято і діє нова стратегія «Інвестуючи в майбутнє дітей: Європейська стратегія охорони здоров'я дітей і підлітків; 2015-2020 рр.», яка закликає забезпечити справедливий доступ до матеріально-санітарних послуг, сприяє реалізації дітьми та підлітками власного потенціалу здоров'я, розвитку і благополуччя, має скоротити тягар запобіжної захворюваності й смертності серед дитячого населення. У свою чергу країни європейського регіону, що виконують стратегію, крім її загальних завдань, що стосуються стимулювання стратегічного керівництва, партнерства і міжсекторальних дій на всіх рівнях суспільства, зміцнення орієнтованої на людину системи охорони здоров'я і потенціалу суспільної охорони здоров'я для поліпшення показників здоров'я та розвитку дітей і підлітків, впливу на соціальні детермінанти здоров'я, а також на проблему нерівності стосовно дітей, підлітків, батьків та опікунів, мають на державному рівні вивчити та визначити власні завдання, які будуть відповідати саме їх специфічним потребам [1-11].

Мета роботи: вивчити, проаналізувати та визначити тенденції стану здоров'я дітей та доступності медичної допомоги домогосподарствам із дітьми за результатами проведених вибіркових досліджень протягом 2012-2016 рр. 
Матеріали і методи. Дослідження з визначення тенденцій проведено на основі даних вибіркових опитувань домогосподарств із дітьми Державної служби статистики України щодо суб'єктивної оцінки стану здоров'я дітей та доступності медичної допомоги домогосподарствам із дітьми за період 2012-2016 рр. Дослідження, що проводили, мали єдині методологічні засади, вибіркові сукупності домогосподарств, які обстежували кожного року, репрезентують все населення України, а отримані дані опитування розповсюджені на генеральну сукупність (всі домогосподарства України) за допомогою процедури статистичного зважування. Використано такі методи: аналітичний, статистичний, порівняльний аналіз, системний підхід.

Результати дослідження та їх обговорення. За результатами дослідження встановлено такі тенденції стану здоров'я дітей за віковими групами (діти до 3-х років, 3-6 років та 7-13 років) і підлітків за віком (14-15 та 16-17 років) та статтю, а саме за даними самооцінки, наданої домогосподарствами із дітьми протягом 2012-2016 рр., частка дітей віком до 3-х років, стан здоров'я яких оцінено як добрий, у 2016 р. складає 80,6 \%, що менше, ніж у 2012 р. на 0,4 \% (80,9 \%), на 2,7\% зменшилась частка даної вікової групи, які оцінили стан здоров'я як задовільний, порівняно 3 2012 р. (2012 р. - 18,1 \%, 2016 р. - 18,6 \% ), частка дітей віком до 3-х років, стан здоров'я яких оцінено як поганий, зросла в 1,6 раза, порівняно 3 2012 р., і склала 1,3 \% у 2016 р. Також варто зазначити, що тенденції до зростання частки дітей та підлітків, які оцінюють стан свого здоров'я як добрий, відбулось серед дітей віком 3-6 років на 4,02 \% відносно 2012 р. (2012 р. - 74,6 \%, 2016 р. 77,6 \%), 7-13 років на 6,6 \% (2012 р. - 73,7\%, 2016 р. - 78,6 \%) хлопчиків віком 14-15 років на 2,1 \% (2012 р. - 74,8 \%, 2016 р. - 76,4 \%), дівчаток віком 14-15 років на 3,9 \% (2012 р. - 73,7 \%, 2016 р. - 76,6 \%), дівчаток віком 16-17 років на 2,8 \% (2012 р. - 74,0 \%, 2016 р. - 76,1 \%), у свою чергу, відбулось зменшення питомої ваги підлітків-хлопчиків віком 16-17 років, які оцінюють своє здоров'я як добре, на 3,3 \% (2012 р. - 78,7\%, 2016 р. - 76,1 \%). Зниження частки дітей та підлітків, які оцінюють своє здоров'я як задовільне, відбулось у наступних вікових групах: діти 3-6 років на 9,8 \% (2012 р. - 23,4 \%, 2016 р. - 21,1 \%), діти 7-13 років на 17,01 \% (2012 р. - 24,1\%, 2016 р. 20,0 \%), хлопчики-підлітки 14-15 років на 1,8 \% (2012 р. - 22,4 \%, 2016 р. - 22,0 \%), дівчатка-підлітки на 11,5 \% (2012 р. - 25,2 \%, 2016 р. - 22,3\%), зростання частки тих, хто вважає своє здоров'я задовільним, зросла серед хлопчиків-підлітків 16-17 років на 19,5 \% (2012 р. - 19,5 \%, 2016 р. 23,3 \%) та дівчаток-підлітків віком 16-17 років на 1,7 \% (2012 р. - 22,9 \%, 2016 р. - 23,3 \%). Протягом
2012-2016 рр. частка дітей та підлітків, які вважають своє здоров'я поганим, зменшилась серед дітей віком 3-6 років на 35,0 \% відносно вихідного року спостереження (2012 р.) і склала у 2016 р. 1,3 \%, у дітей віком 7-13 років на 36,4 \% (2016 р. 1,4\%), у хлопчиків-підлітків віком 14-15 роки на 42,9 \% (2016 р. - 1,6 \%), у хлопчиків-підлітків віком 16-17 років на 66,7 \% (2016 р. - 0,6 \%), серед дівчаток-підлітків 16-17 років відбулось зниження частки тих, хто оцінює свій стан здоров'я як поганий (з 3,0 \% у 2012 р. до 0,6 \% у 2016 р.), без змін (2,2 \% як у 2012 р., так і 2016 р.) залишилась частка дівчаток-підлітків віком 14-15 років, які оцінюють власний стан здоров'я як поганий, зростання частки тих, хто вважає свій стан здоров'я поганим, відбулось лише серед дітей віком до 3-х років (як це було зазначено вище).

Частка осіб, які повідомили, що хворіли за останні 12 місяців, збільшилась майже за всіма дитячими віковими групами: діти до 3-х років на 7,42 \% у 2016 р., порівняно 32012 р., діти 3-6 років на 7,6 \% відповідно, діти 7-13 років на 3,1 \%, хлопчики-підлітки 14-15 років на 8,2 \%, хлопчикипідлітки 16-17 років на 27,5 \%, дівчатка-підлітки 14-15 років на 39,4 \%, і лише частка дівчаток-підлітків віком 16-17 років, які повідомили, що хворіли за останні 12 місяців, зменшилася на 1,1\% до вихідного року дослідження (2012р.). Якщо аналізувати тенденції щодо хронічної захворюваності дитячого населення за даними вибіркового опитування, спостерігають зростання частки кількості осіб серед усіх осіб у відповідному віці, які повідомили, що мають хронічні захворювання (6 місяців та більше) або проблеми зі здоров'ям серед дітей віком до 3-х років (3 3,9 \% у 2012 р. до 5,8 \% у 2016 р.), дітей віком 3-6 років (3 7,7 \% до 10,44 \% відповідно), хлопчиків-підлітків віком 16-17 років (3 7,8 \% до $12,4 \%$ ), дівчаток-підлітків (3 10,4 \% до 13,6 \%) та зменшення частки серед дітей віком 7-13 років (з 11,8 у 2012 р. до 10,75 \% у 2016 р.), хлопчиків-підлітків віком 14-15 років (3 14,6 \% у 2012 р. до 13,8 \% у 2016 р.), серед дівчаток-підлітків віком 14-15 років (з 14,4 \% у 2012 р. до 11,9 \% у 2016 р.) За аналізований період привертає увагу тенденція зростання питомої ваги дитячого населення, які повідомили, що зверталися за медичною допомогою протягом останніх 12 місяців, так у віці до 3-х років частка звернень зросла в 2012 р. $з 93$ \% до 99,6 \% у 2016 р., у віці 3-6 років з $94 \%$ до 98,9 \%, 7-13 років з 93,6 \% до 97,5\%, серед дівчаток-підлітків віком 14-15 років з 94,6 \% до 95,0 \%, дівчаток-підлітків 16-17 років з 94,6 \% до 98,7 \% відповідно, і тільки спостерігають тенденції до зниження частки кількості осіб, які звертались за медичною допомогою, серед хлопчиківпідлітків 14-15 років з 97,3 \% у 2012 р. до 96,7 \% у 2016 р. та хлопчиків-підлітків віком 16-17 років з 97,8 \% до 96,7 \% відповідно. Найчастіше ті діти 
та підлітки, які зверталися за медичною допомогою протягом останніх 12 місяців, відвідували поліклініки (крім стоматолога) у 2016 р.: 90,9 \% (діти до 3-х років), 91,2 \% (діти 3-6 років), 89,8 \% (діти 7-13 років), 87,1 \% та 86,5 \% (хлопчики-підлітки 14-15 та 16-17 років відповідно), 86,0 \% та 92,9 \% (дівчатка-підлітки 14-15 та 16-17 років відповідно), а також сімейного лікаря у поліклініці (від 19,2 \% до 26,2 \% звернень), стоматолога у державній медичній установі, звернення до якого зростають з віком дитини (1,9\% дітей до 3-х років звертаються за даним видом допомоги, 13,7 \% у 3-6 років, 16,4 \% - у 7-13 років, 7,6 \% хлопчиків 14-15 років, 19,2 \% хлопчиків 16-17 років, $16,9 \%$ і 22,6 \% у дівчаток 14-15 та 16-17 років відповідно), найвищу частку звернень за швидкою медичною допомогою спостерігають серед дітей віком до 3-х та 3-6 років (у 2016 р.: 3,2 \% та 2,3\% відповідно серед тих, хто звертався за медичною допомогою протягом останніх 12 місяців, і частка осіб, які звертаються за швидкою допомогою, зросла відповідно до попередніх років та вихідного 2012 р.: 2,5 \% - діти до 3-х років, 1,0 \% - діти 3-6 років), також діти віком до 3-х, 3-6 та 7-13 років спостерігають звернення до платних медичних установ або приватного практикуючого лікаря (крім стоматолога), частка яких зростає (у 2016 р.: 4,6 \% - до 3-х років, 4,0 \% - 3-6 років, 2,2 \% - 7-13 років; 2012 р.: 2,6 \%, 2,3 \%, 1,1 \% відповідно). Частка осіб дитячого віку із загальної кількості осіб кожної з дитячих вікових груп, які при опитуванні повідомили, що за останні 12 місяців вони лікувались у лікарні і брали з собою медикаменти, склала у 2016 р. 84,4 \% серед дітей віком до 3-х років (82,2 \% - у 2012 р.), 93,6 \% у віці 3-6 років (87,3 \% - у 2012 р.), 94,9\% у віці 7-13 років (89,1 \% - у 2012 р.), $100 \%$ та 79,6 \% у хлопчиків-підлітків 14-15 та 16-17 років відповідно (100 \% і 89,0\% у 2012 р.), 100 \% і 51,8 \% у дівчаток віком 14-15 та 16-17 років відповідно, таким чином простежують чіткі тенденції щодо зростання частки дітей у всіх вікових групах, які беруть до лікарні медикаменти, придбані за власний кошт. Також у більшості дитячих вікових груп спостерігають тенденції і до зростання частки осіб дитячого віку, які до лікарні брали з собою постільну білизну $(68,8 \% ; 85,0 \% ; 66,1 \% ; 44,6 \% ; 83,6 \% ; 100 \%$; 51,8 \% у 2016 р. відповідно до вікових груп діти до 3-х, 3-6 та 7-13 років, хлопчики-підлітки 14-15 та 16-17 років, дівчатка-підлітки 14-15 і 16-17 років відповідно, тоді як у 2012 р.: 59,6 \%; 56,2 \%; 68,9\%; 66,3 \%; 83,4 \%; 94,9 \%; 85,5 \% відповідно), аналогічні тенденції спостерігають і щодо харчування.

Частка домогосподарств із дітьми до загальної кількості відповідних домогосподарств, у яких хтось із членів протягом останніх 12 місяців потребував медичної допомоги, придбання ліків або медичного приладдя протягом 2012-2016 рр. залишається на відносно постійному рівні $(98,7-$ 99,1 \%). Частка домогосподарств із дітьми, члени яких останні 12 місяців при потребі не змогли отримати медичну допомогу, придбати ліки та медичне приладдя у 2016 р. зросла на 37,2 \% відносно 2012 р. і склала 19,9 \%, (у 2012 р. - 14,5 \%). Більшість домогосподарств із дітьми, які потребували медичної допомоги, вказали при опитуванні, що не змогли її отримати у необхідному обсязі, а саме: не змогли придбати необхідні ліки, медичні приладдя, відвідати лікаря (в тому числі й стоматолога), зробити протезування, провести медичне обстеження, отримати лікувальні процедури, лікування в стаціонарі з причини занадто високої вартості медичних виробів, послуг, лікування тощо (табл. 1).

Таблиця 1. Динаміка розподілу домогосподарств за рівнем доступності медичної допомоги, можливості придбання ліків та медичного приладдя

\begin{tabular}{|c|c|c|c|c|c|}
\hline & 2012 p. & 2013 p. & 2014 p. & 2015 p. & 2016 p. \\
\hline \multirow{2}{*}{$\begin{array}{l}\text { Кількість домогосподарств, члени яких протягом останніх } \\
12 \text { місяців потребували медичної допомоги, придбання ліків } \\
\text { та медичного приладдя (тис.) } \\
\text { - відсоток до загальної кількості домогосподарств } \\
\text { відповідної групи (\%) }\end{array}$} & 6361,5 & 6344,4 & 5834,8 & 5682,8 & 5669,6 \\
\hline & 98,8 & 98,7 & 99,1 & 98,8 & 98,7 \\
\hline \multirow{2}{*}{$\begin{array}{l}\text { Кількість домогосподарств, члени яких останні } 12 \text { місяців при } \\
\text { потребі не змогли отримати медичної допомоги, придбати } \\
\text { ліки та медичне приладдя (тис.) } \\
\text { - відсоток до кількості домогосподарств, у яких члени } \\
\text { потребували медичної допомоги, придбання ліків та } \\
\text { медичного приладдя }\end{array}$} & 925,4 & 1197,9 & 1043,4 & 1354,6 & 1128,8 \\
\hline & 14,5 & 18,9 & 17,9 & 23,8 & 19,9 \\
\hline \multirow{4}{*}{$\begin{array}{l}\text { Кількість домогосподарств (тис.), у яких хтось із членів не } \\
\text { зміг: придбати ліки, у тому числі з причин (\%): } \\
\text { - занадто висока вартість } \\
\text { - не змогли знайти } \\
\text { - інше }\end{array}$} & 781,6 & 980,1 & 913,9 & 1168,5 & 898,7 \\
\hline & 94,4 & 94,8 & 92,9 & 96,6 & 95,2 \\
\hline & 5,4 & 3,8 & 6,9 & 2,4 & 4,4 \\
\hline & 0,2 & 1,4 & 0,2 & 1,0 & 0,4 \\
\hline
\end{tabular}


Продовження табл. 1

\begin{tabular}{|c|c|c|c|c|c|}
\hline \multirow{4}{*}{$\begin{array}{l}\text { Придбати медичне приладдя (тuс.) } \\
\text { у тому числі з причин (\%): } \\
\text { - занадто висока вартість } \\
\text { - не змогли знайти } \\
\text { - інше }\end{array}$} & 106,3 & 182,8 & 125,5 & 184,7 & 189,9 \\
\hline & 96,7 & 89,4 & 98,2 & 95,3 & 95,8 \\
\hline & 1,3 & - & 1,8 & 1,4 & - \\
\hline & 2,0 & 10,6 & - & 3,3 & 4,2 \\
\hline \multirow{4}{*}{$\begin{array}{l}\text { Відвідати лікаря (тис.) } \\
\text { у тому числі (\%): } \\
\text { - через високу вартість } \\
\text { - черга занадто довга } \\
\text { - відсутність спеціаліста необхідного профрілю } \\
\text { - занадто висока вартість послуг }\end{array}$} & & & & & \\
\hline & $\begin{array}{c}551,6 \\
163\end{array}$ & $\begin{array}{c}709,1 \\
99\end{array}$ & $\frac{576,1}{79}$ & $\frac{806,6}{79}$ & $\frac{682,1}{6.3}$ \\
\hline & 10,5 & 10,4 & 16,9 & 9,9 & 12,2 \\
\hline & 73,2 & 79,7 & 75,2 & 82,2 & 81,5 \\
\hline \multirow{4}{*}{$\begin{array}{l}\text { Відвідати стоматолога (muc.) } \\
\text { у тому числі з причин (\%): } \\
\text { - черга занадто довга } \\
\text { - відсутність спеціаліста необхідного профілю } \\
\text { - занадто висока вартість послуг }\end{array}$} & 372,9 & 516,3 & 428,3 & 558,2 & 479,3 \\
\hline & 1,8 & 0,6 & 1,1 & - & - \\
\hline & 1,2 & 0,4 & 1,9 & 0,3 & 2,6 \\
\hline & 97,2 & 99,0 & 97,0 & 99,7 & 97,4 \\
\hline \multirow{4}{*}{$\begin{array}{l}\text { Зробити протезування (muc.) } \\
\text { у тому числі з причин (\%): } \\
\text { - черга занадто довга } \\
\text { - відсутність спеціаліста необхідного профрілю } \\
\text { - занадто висока вартість послуг }\end{array}$} & 183,5 & 235,2 & 190,9 & 246,3 & 245,3 \\
\hline & - & - & - & - & - \\
\hline & 1,6 & - & 1,0 & - & 2,1 \\
\hline & 98,4 & 100 & 99,0 & 100 & 97,9 \\
\hline \multirow{4}{*}{$\begin{array}{l}\text { Провести медичні обстеження (тис.) } \\
\text { у тому числі з причин (\%): } \\
\text { - черга занадто довга } \\
\text { - відсутність спеціаліста необхідного профрілю } \\
\text { - занадто висока вартість послуг }\end{array}$} & 450,9 & 574,6 & 439,1 & 716,0 & 617,5 \\
\hline & 4,8 & 3,3 & 0,4 & 2,1 & 3,5 \\
\hline & 8,0 & 10,9 & 7,1 & 4.3 & 7,3 \\
\hline & 87,2 & 85,8 & 92,5 & 93,6 & 89,2 \\
\hline \multirow{4}{*}{$\begin{array}{l}\text { Отримати лікувальні процедури (muc.) } \\
\text { у тому числі з причин (\%): } \\
\text { - черга занадто довга } \\
\text { - відсутність спеціаліста необхідного профрілю } \\
\text { - занадто висока вартість послуг }\end{array}$} & 214,0 & 305,9 & 274,0 & 332,2 & 280,8 \\
\hline & 1,8 & - & 0,1 & 0,8 & - \\
\hline & 2,0 & 2,2 & 0,7 & 2,1 & 3,2 \\
\hline & 96,2 & 97,8 & 99,2 & 97,1 & 96,8 \\
\hline \multirow{4}{*}{$\begin{array}{l}\text { Отримати лікування у стаціонарі (muc.) } \\
\text { у тому числі з причин (\%): } \\
\text { - відсутність вільних місць } \\
\text { - відсутність відділення необхідного профрілю } \\
\text { - занадто висока вартість лікування }\end{array}$} & 182,4 & 483,6 & 201,6 & 504,9 & 266,3 \\
\hline & 2,5 & 0,7 & 0,2 & 1,6 & - \\
\hline & 7,6 & 5,5 & 3,0 & 0,4 & 9,0 \\
\hline & 89,9 & 93,8 & 96,8 & 98,0 & 91,0 \\
\hline
\end{tabular}

\section{Висновки}

За даними суб'єктивної оцінки стану здоров'я дітей та підлітків протягом 2012-2016 рр. зменшилась частка дітей віком до 3-х років та хлопчиків-підлітків віком 16-17 років, які оцінюють власне здоров'я як добре; також зменшилась частка дітей, які оцінюють своє здоров'я як задовільне, у віковій групі діти до 3-х років, 3-6 та 7-13 років, хлопчики-підлітки та дівчатка-підлітки віком 14-15 років; зросла частка дітей до 3-х років, які оцінюють власний стан здоров'я як поганий. Майже за всіма дитячими віковими групами спостерігають тенденцію до зростання частки осіб, які повідомили, що хворіли останні 12 місяців, також зростає кількість дитячого населення, які мають хронічні захворювання в більшості дитячих вікових груп. Встановлено тенденцію до зростання кількості осіб, які звертались за медичною допомогою протягом останніх 12 місяців; також дітей віком до 3-х та 3-6 років зростає кількість звернень за швидкою медичною допомогою та у приватні медичні установи; зросла частка осіб дитячого віку, які мають брати із собою до лікарні медикаменти, постільну білизну, їжу, до того ж зростає частка домогосподарств із дітьми, що при потребі не змогли отримати медичну допомогу, придбати ліки та медичне приладдя, що відбувається з причини високої вартості медичного приладдя, послуг, лікування.

Перспективи подальших досліджень полягають у вивченні та науковому обґрунтуванні оптимізації існуючої системи надання медичних послуг у напрямі загального охоплення медико-санітарною допомогою дитячого населення країни, комплексності надання медичних послуг та максимальної орієнтації послуг на актуальні потреби, що сприятиме покращенню здоров'я дітей та підлітків. 


\section{Список літератури}

1. Документ EUR/RC62/12 Rev.1. Европейский план действий по укреплению потенциала и услуг общественного здравоохранения [Электронный ресурс]. - Копенгаген : Европейское региональное бюро ВОЗ, 2012. - Режим доступа : (http://www.euro.who.int/_data/assets/pdf_file/0008/171773/RC62wd12rev1-Rusupdated.pdf?ua=1, по coстоянию на 11 июля 2014 г.).

2. Здоровье-2020: основы европейской политики в поддержку действий всего государства и общества в интересах здоровья и благополучия. - Копенгаген : Европейское региональное бюро ВОЗ, 2012. - 18 с.

3. Инвестируя в будущее детей: Европейская стратегия охраны здоровья детей и подростков, 2015-2020 гг. I Европейский региональный комітет, 64 сессия, Копенгаген, Дания, 15-18 сентября 2014 г. - 28 с.

4. Резолюция EUR/RC55/R6. Европейская стратегия «Здоровье и развитие детей и подростков» [Электронный ресурс]. - Копенгаген : Европейское региональное бюро ВО3, 2005. - Режим доступа : (http://www.euro.who.int/_ data/assets/pdf file/0011/88085/RC55 rres06.pdf, по состоянию на 30 июня 2014 г.).

5. Резолюция WHA64.28. Молодежь и риски для здоровья. Опубликовано в: Шестьдесят четвертая сессия Всемирной ассамблеи здравоохранения, Женева, 16-24 мая 2011 г. Резолюции и решения, приложения. - Женева : Всемирная организация здравоохранения. - 2011. - 28 (документ WHA64/2011/REC/1. - Режим доступа : - http:// apps.who.int/gb/ebwha/pdf_files/WHA64REC1/A64_REC1-ru.pdf\#page=23, по состоянию на 30 июня 2014 г.).

6. Adamson P. Child well-being in rich countries. A comparative overview / P. Adamson. - Florence: UNICEF Office of Research; 2013 (Innocenti Report Card 11).

7. Brady C. Integrating the life-course into $\mathrm{MCH}$ service delivery: From theory to practice / C. Brady, F. Johnson // Matern. Child Health J. - 2013. - Vol. 17. - P. 586-592.

8. Improving the lives of children and young people: Case studies from Europe. Volume 1. Early years. Copenhagen: WHO Regional Office for Europe; 2013.

9. Improving the lives of children and young people: Case studies from Europe. Volume 2. Childhood. Copenhagen: WHO Regional Office for Europe; 2013.

10. Improving the lives of children and young people: Case studies from Europe. Volume 3. School. Copenhagen: WHO Regional Office for Europe; 2013

11. Wolfe I. European child health services and systems: Lessons without borders / I. Wolfe, M. McKee; eds. - Brussels: European Observatory on Health Systems and Policies; 2013.

\section{References}

1. (2012). Dokument EUR/RC62/12 Rev.1. Yevropeyskiy plan deystviy po ukrepleniyu potentsiala i uslug obshchestvennogo zdravookhraneniya. Kopengagen: Yevropeyskoye regionalnoye byuro VOZ [Document EUR / RC62 / 12 Rev.1. European Action Plan for Strengthening Public Health Capacity and Services. Copenhagen: WHO Regional Office for Europe]. Retrieved from: (http://www.euro.who.int/_data/assets/pdf_file/0008/171773/RC62wd12rev1-Rusupdated.pdf?ua=1, po sostoyaniyu na 11 iyulya 2014 g.) [in Russian].

2. (2012). Zdorovye-2020: Osnovy Yevropeyskoy politiki v podderzhku deystviy vsego gosudarstva i obshchestva $v$ interesakh zdorovya i blagopoluchiya. Kopengagen: Yevropeyskoye regionalnoye byuro VOZ [Health 2020: The foundations of European policy in support of the actions of the entire state and society for health and well-being. Copenhagen: WHO Regional Office for Europe]. [in Russian].

3. Investiruya $v$ budushcheye detey: Yevropeyskaya strategiya okhrany zdorovya detey i podrostkov, 2015-2020 gg. [Investing in the future of children: European Strategy for the Health of Children and Adolescents, 2015-2020]. Yevropeyskiy regionalnyy komitet, 64 sessiya, Kopengagen, Daniya 15-18 sentyabrya 2014 g. - European Regional Committee, 64th Session, Copenhagen, Denmark 15-18 September 2014, 28 [in Russian].

4. (2005). Rezolyutsiya EUR/RC55/R6. Yevropeyskaya strategiya "Zdorovye i razvitiye detey i podrostkov. Kopengagen: Yevropeyskoye regionalnoye byuro VOZ [Resolution EUR / RC55 / R6. European strategy "Health and development of children and adolescents". Copenhagen: WHO Regional Office for Europe]. - Retrieved from: http://www.euro.who.int/_ data/assets/pdf_file/0011/88085/RC55_rres06.pdf, po sostoyaniyu na 30 iyunya $2014 \mathrm{~g}$ [in Russian].

5. Rezolyutsiya WHA64.28. Molodezh i riski dlya zdorovya. Opublikovano v: Shestdesyat chetvertaya sessiya Vsemirnoy assamblei zdravookhraneniya, Zheneva, 16-24 maya $2011 \mathrm{~g}$. Rezolyutsii i resheniya, prilozheniya. Zheneva: Vsemirnaya organizatsiya zdravookhraneniya; 2011:28 (dokument WHA64/2011/REC/1 [Resolution WHA64.28. Youth and health risks. Published in: Sixty-fourth World Health Assembly, Geneva, May 16-24, 2011. Resolutions and decisions, annexes. Geneva: World Health Organization; 2011: 28 (document WHA64 / 2011 / REC / 1]. - Retrieved from: http://apps.who.int/ gb/ebwha/pdf_files/WHA64REC1/A64_REC1-ru.pdf\#page=23, po sostoyaniyu na 30 iyunya 2014 g.) [in Russian]. 6. Adamson, $\bar{P}$. (2013). Child well-being in rich countries. A comparative overview. Florence: UNICEF Office of Research; (Innocenti Report Card 11).

7. Brady, C., \& Johnson, F. (2013). Integrating the life-course into MCH service delivery: From theory to practice. Matern. Child Health J., 17, 586-592.

8. Improving the lives of children and young people: Case studies from Europe. Volume 1. Early years. Copenhagen: WHO Regional Office for Europe; 2013.

9. Improving the lives of children and young people: Case studies from Europe. Volume 2. Childhood. Copenhagen: WHO Regional Office for Europe; 2013.

10. Improving the lives of children and young people: Case studies from Europe. Volume 3. School. Copenhagen: WHO Regional Office for Europe; 2013

11. Wolfe, I., McKee, M., (Eds.). (2013). European child health services and systems: Lessons without borders. Brussels: European Observatory on Health Systems and Policies. 
ТЕНДЕНЦИИ СОСТОЯНИЯ ЗДОРОВЬЯ ДЕТСКОГО НАСЕЛЕНИЯ И ДОСТУПНОСТИ МЕДИЦИНСКОЙ ПОМОЩИ (по данным выборочного опроса домохозяйств с детьми)

Г.А. Слабкий ${ }^{1}$, С.В. Дудник²

1ГВУЗ «Ужгородский национальный университет», г. Ужгород, Украина

2ГУ «Украинский институт стратегических исследований Министерства здравоохранения Украины», г. Киев, Украина

Цель: изучить, проанализировать и определить тенденции состояния здоровья детей и доступности медицинской помощи домохозяйствам с детьми по результатам выборочных исследований в течение 2012-2016 гг.

Материалы и методы. Исследование проведено на основании данных выборочных опросов домохозяйств с детьми Государственной службы статистики Украины относительно субъективной оценки состояния здоровья детей и доступности медицинской помощи домохозяйствам с детьми за период 2012-2016 гг. Использованы методы: аналитический, статистический, сравнительный анализ, системный подход.

Результаты. В ходе исследования, по данным субъективной оценки, определены тенденции в оценке состояния здоровья детей, заболеваемости и наличии хронической патологии у детей, доступности медицинской помощи и ее видов домохозяйствам с детьми за период 2012-2016 гг.

Выводы. Установленные тенденции состояния здоровья детского населения и неудовлетворительный уровень доступности медицинской помощи требуют оптимизации системы предоставления медицинских услуг и медико-санитарной помощи детскому населению страны в целом.

КЛЮЧЕВЫЕ СЛОВА: здоровье детей; доступность медицинской помощи; тенденции состояния здоровья; домохозяйства с детьми.

\author{
TENDENCIES OF CHILDREN'S HEALTH AND ACCESSIBILITY OF MEDICAL CARE (according to a \\ sample survey of households with children) \\ G.A. Slabkiy ${ }^{1}$, S.V. Dudnyk ${ }^{2}$ \\ 1 Uzhhorod National University, Uzhhorod, Ukraine \\ 2Ukrainian Institute of Strategic Researches of Ministry of Public Health of Ukraine, Kyiv, Ukraine
}

Purpose: to study, analyze and determine trends of children's health and accessibility of medical care for households with children based on the results of sample surveys during 2012-2016.

Materials and Methods. The study was conducted on the basis of data from sample surveys of households with children of the State Statistics Service of Ukraine on a subjective assessment of the health status of children and accessibility of medical care for households with children for the period 2012-2016. Methods: analytical, statistical, comparative analysis, system approach.

Results. During the study, according to the subjective assessment, tendencies of estimation the health status of children, the morbidity and presence of chronic pathology among children, the availability of medical care and its types to households with children during the period 2012-2016 were determined.

Conclusions. The established tendencies of the health status of children and the unsatisfactory level of accessibility of medical care require the optimization of the system of providing medical services and medicalsanitary care for children of the country as a whole.

KEY WORDS: children's health; accessibility of medical care; tendencies of children's health; households with children.

Рукопис надійшов до редакції 09.07.2018 p.

Відомості про авторів:

Слабкий Геннадій Олексійович - доктор медичних наук, професор, завідувач кафедри громадського здоров'я ДВНЗ «Ужгородський національний університет».

Дудник Світлана Валеріївна - кандидат медичних наук, учений секретар ДУ «Український інститут стратегічних досліджень Міністерства охорони здоров'я України». 